Nursing Arts

Vol 12, No 2 Desember 2018,

ISSN: 1978-6298 (Print)

\title{
EVALUASI PROSES PEMBELAJARAN BERDASARKAN HASIL TRY OUT UJI KOMPETENSI PRODI DIII KEPERAWATAN
}

\author{
Radeny Ramdany ${ }^{1}$, M. Loihala ${ }^{2}$, Yogik Setia Anggreini ${ }^{2}$ \\ ${ }^{1}$ Jurusan Gizi Poltekkes Kemenkes Sorong \\ ${ }^{2}$ Jurusan Keperawatan Poltekkes Kemenkes Sorong \\ E-mail : radeny_ramdany@yahoo.com
}

\author{
Artikel history \\ Dikirim, Agustus $4^{\text {th }}, 2018$ \\ Ditinjau, September $19^{\text {th }}, 2018$ \\ Diterima, Desember $13^{\text {th }}, 2018$
}

\begin{abstract}
Background: In accordance with the mandate of Law No. 12/2012 on Higher Education, the government has implemented a higher education quality assurance system in the health sector, one of which is the implementation of national competency tests. Sorong's DIII Nursing Polytechnic Study Program since 2014 has conducted a competency exam, but the graduation rate is still low, namely in 2017 at $64 \%$. One of the factors that influence the passing of the competency test is the learning process carried out by the lecturer. Therefore it is necessary to evaluate the learning process based on the results of the competency test try out.Method: The project was conducted in October 2018. The method used was descriptive qualitative with a case study approach. The evaluation included teaching materials, teaching materials, learning methods, assessment of learning outcomes and teaching staff. The subjects in this study were students and lecturers of KMB I, KMB II, and Emergency Nursing as subjects that had the highest and lowest graduation percentages based on the results of study program competency test DIII Nursing Sorong for the period February 2018. Data collection was done using studies interview documents and guidelines. Data validity uses triangulation and data analysis techniques using interactive reduction.Results: Based on the results of interviews and study documents, it was found that the highest percentage of KMB graduation at the competency test try out was influenced by teaching material thoroughly and clearly, teaching materials that used references from various sources, varied and innovative learning methods, learning outcomes assessment using questions similar to the competency exam, and the teaching staff that matches the qualifications. This is inversely proportional to the Emergency Nursing course.Conclusion: The low results of the competency test try-out are influenced by the learning process by the lecturers including teaching materials, learning resources, learning methods, assessment of learning outcomes, and teaching staff.
\end{abstract}

Keywords: Learning, Competency Test, Nursing

ABSTRAK

Latar Belakang : Sesuai amanah UU No.12/2012 tentang Pendidikan Tinggi, pemerintah telah menyelenggarakan sistem penjaminan mutu pendidikan tinggi bidang kesehatan, salah satunya adalah penyelenggaraan uji kompetensi secara nasional. Program Studi DIII Keperawatan Poltekkes Kemenkes Sorong sejak tahun 2014 sudah melakukan ujian kompetensi, namun tingkat kelulusannya masih rendah yaitu pada tahun 2017 sebesar 64\%. Salah satu yang mempengaruhi kelulusan uji kompetensi adalah proses pembelajaran yang dilakukan oleh dosen. Oleh karena itu perlu dilakukan evaluasi proses pembelajaran berdasarkan hasil try out uji kompetensi.Metode : Project dilaksanakan pada bulan Oktober 2018. Metode yang digunakan adalah deskriptif kualitatif dengan pendekatan studi kasus. Evaluasi yang dilakukan meliputi materi ajar, bahan ajar, metode pembelajaran, penilaian hasil belajar dan staf pengajar. Subyek dalam penelitian ini adalah mahasiswa dan dosen mata kuliah KMB I, KMB II, dan Keperawatan Gawat Darurat sebagai mata kuliah yang memiliki persentase kelulusan tertinggi dan terendah berdasarkan hasil try out uji kompetensi Prodi DIII Keperawatan Sorong periode bulan Februari 2018. Pengumpulan data dilakukan menggunakan studi dokumen dan pedoman wawancara. Validitas data menggunkaan teknik triangulasi dan analisis data menggunakan interaktif reduksi.

Hasil : Berdasarkan hasil wawancara dan studi dokumen ditemukan bahwa persentase kelulusan KMB tertinggi pada try out uji kompetensi dipengaruhi oleh materi ajar disampaikan secara tuntas dan jelas, bahan ajar yang menggunkaan referensi dari berbagai sumber, metode pembelajaran yang variatif dan inovatif, penilaian hasil belajar menggunakan soal serupa dengan ujian kompetensi, dan staf pengajar yang sesuai kualifikasi. Hal ini berbanding terbalik dengan mata kuliah Keperawatan Gawat Darurat.Kesimpulan : Rendahnya hasil try out uji kompetensi dipengaruhi oleh proses pembelajaran oleh dosen antara lain materi ajar, sumber belajar, metode pembelajaran, penilaian hasil belajar, dan staf pengajar.

Kata Kunci : Pembelajaran, Uji Kompetensi, Keperawatan 


\section{PENDAHULUAN}

Dalam upaya menjamin mutu pendidikan tinggi bidang kesehatan, sesuai amanah UU No.12/2012 tentang Pendidikan Tinggi, pemerintah telah menyelenggarakan sistem penjaminan mutu pendidikan tinggi bidang kesehatan, yang salah satu kebijakan utamanya adalah penyelenggaraan uji kompetensi secara nasional. Bidang kesehatan yang telah menjalankan uji kompetensi secara kesehatan di Indonesia. Uji kompetensi nasional diharapkan mampu menyaring tenaga kesehatan Indonesia yang kompeten untuk memberikan pelayanan kesehatan secara paripurna kepada masyarakat, dengan prinsip utama keselamatan pasien. Dari sisi pendidikan, uji kompetensi nasional diharapkan dapat mendorong perbaikan kurikulum dan proses pembelajaran di tiap institusi pendidikan, dan menjadi dasar pembinaan mutu pendidikan bidang kesehatan yang menjadi tanggung jawab Kementerian.

Program Studi DIII Keperawatan sebagai salah satu program studi yang ada di Poltekkes Kemenkes Sorong sejak tahun 2014 sudah melakukan ujian kompetensi, namun tingkat kelulusan ujian kompetensi DIII Keperawatan Poltekkes Sorong masih rendah. Persentase kelulusan ujian kompetensi dalam 3 tahun terakhir yaitu pada tahun 2015 sebesar 22,2\%, tahun 2016 sebesar 15,58\%, dan tahun 2017 sebesar 64\%. Meskipun persentase kelulusan dari tahun ke tahun semakin meningkat namun angka ini masih jauh tertinggal dibanding ratarata nasional yaitu $80 \%$.

Berdasarkan hasil try out uji kompetensi program studi DIII Keperawatan Sorong periode $10 \quad$ Februari 2018 menunjukkan bahwa dari 8 area kompetensi yang memiliki nilai kelulusan tertinggi yaitu area kompetensi Keperawatan Medikal Bedah

\section{METODE}

\section{A. Metode Project}

Metode yang digunakan pada project ini adalah deskriptif kualitatif dengan pendekatan studi kasus untuk menjelaskan bagaimana proses pembelajaran oleh dosen yang mengajar mata kuliah dengan persentase kelulusan tertinggi dan terendah berdasarkan hasil try out uji kompetensi Prodi DIII Keperawatan Sorong yaitu mata kuliah Keperawatan Medikal Bedah dan Keperawatan Gawat Darurat. nasional hingga saat ini adalah kedokteran, kedokteran gigi, keperawatan, kebidanan dan ners. Uji kompetensi nasional ini diharapkan dapat mengurangi disparitas kualitas lulusan dari sekitar 2200 program studi bidang kesehatan. Dalam hal tantangan global, uji kompetensi nasional merupakan bagian dari upaya standardisasi registrasi dan izin praktik bagi tenaga kesehatan yang akan memberikan pelayanan

dengan jumlah rata-rata jawaban benar 20,69 dari 56 soal $(36,9 \%)$ sementara yang terendah yaitu area kompetensi Keperawatan Gawat Darurat dengan rata-rata jumlah jawaban benar 3,56 dari 12 soal $(29,7 \%)$.

Rendahnya hasil uji kompetensi ini dipengaruhi oleh beberapa faktor baik internal maupun eksternal. Faktor internal meliputi : kecerdasan, minat dan bakat, serta motivasi peserta. Sedangkan faktor eksternal meliputi : try out, kurikulum/metode pembelajaran, dan proses belajar mengajar yang dilakukan oleh dosen.

Hasil observasi awal terhadap proses pembelajaran oleh dosen menunjukkan belum sepenuhnya sesuai. Selain itu diketahui masih ada materi perkuliahan yang tidak disampaikan secara tuntas kepada mahasiswa. Evaluasi hasil try out uji kompetensi belum pernah dilakukan sebelumnya. Berdasarkan latar belakang masalah tersebut, maka kami tertarik untuk melakukan project : "Evaluasi Proses Pembelajaran Berdasarkan Hasil Try Out Uji Kompetensi Prodi DIII Keperawatan Poltekkes Kemenkes Sorong" guna mencapai kualitas pembelajaran yang lebih baik yang pada akhirnya dapat meningkatkan angka kelulusan ujian kompetensi khususnya pada mata kuliah yang tingkat kelulusannya rendah.

\section{B. Subyek} adalah:

Adapun subyek dalam penelitian ini

1. Dosen mata kuliah Keperawatan Medikal Bedah I, Keperawatan Medikal Bedah II dan Keperawatan Gawat Darurat dan Manajemen Bencana yang mengajar pada TA. 2017/2018 berjumlah 3 orang.

2. Mahasiswa yang telah mengikuti try out uji kompetensi DIII Keperawatan 
periode 10 Februari 2018 sebanyak 4 mahasiswa.

\section{Instrumen Penelitian}

Instrumen evaluasi hasil try out uji kompetensi menggunakan pedoman wawancara untuk menggali informasi tentang bagaimana proses pembelajaran oleh dosen yang mengajar mata kuliah Keperawatan Medikal Bedah I, Keperawatan Medikal Bedah II dan Keperawatan Gawat Darurat dan Manajemen Bencana. Aspek yang ditanyakan meliputi materi ajar, bahan ajar, metode pembelajaran, penilaian hasil belajar, dan staf pengajar.

\section{Tahapan Prosedur}

\section{E. Pengumpulan dan Analisis Data}

Pengumpulan data dilakukan melalui telaah dokumen dan wawancara mendalam terhadap subyek penelitian (dosen dan mahasiswa) menggunakan pedoman wawancara. Validitas data menggunkaan teknik triangulasi. Triangulasi yang digunakan adalah: (1) Triangulasi data, yaitu: dengan cara mengumpulkan data sejenis dari sumber berbeda. Dengan teknik ini diharapkan dapat memberikan informasi yang lebih tepat sesuai dengan keadaan. Sumber data yang dimaksudkan bersumber dari dosen dan mahasiswa. (2) Triangulasi metode, yaitu: dilakukan dengan mengumpul data

HASIL

\section{Deskripsi Hasil Try Out Uji Kompetensi}

Prodi DIII Keperawatan Poltekkes

Kemenkes Sorong telah mengikuti Try Out Uji Kompetensi yang diselenggarakan oleh
Project ini dilakukan pada bulan Oktober 2018. Sumber data berasal dari telaah dokumen dan wawancara terhadap dosen dan mahasiswa.

Adapun tahapan prosedur dalam project ini yaitu :

1. Mengumpulkan dokumen yang dibutuhkan antara lain data hasil try out uji kompetensi dari AIPViKi, RPS, lembar monitoring dosen, bahan ajar, soal ujian, serta kurikulum prodi DIII Keperawatan.

2. Melakukan wawancara terhadap dosen dan mahasiswa terkait proses pembelajaran ketiga mata kuliah

3. Menarik kesimpulan

sejenis tetapi dengan menggunakan teknik pengumpulan data yang berbeda. Dalam project ini pengumpulan data dilakukan melalui studi dokumen dan wawancara. Penggunaan metode pengumpulan data yang berbeda ini diusahakan mengarah pada sumber data yang sama untuk menguji kemantapan informasinya Analisis data menggunakan interaktif reduksi dengan teknik deskripsi kualitatif yang meliputi tahap penyediaan data, reduksi data, sajian data, dan penarikan kesimpulan. Semua proses wawancara direkam. Hasil wawancara disajikan dalam bentuk narasi.

Asosiasi Institusi Pendidikan Vokasi Keperawatan Indonesia (AIPViKI) pada tanggal 10 Februari 2018 dengan jumlah peserta sebanyak 63 mahasiswa, dengan hasil sebagai berikut :

Tabel.3.1 Tabel Persentase Jawaban Benar Berdasarkan Area Kompetensi Try Out Uji Kompetensi Prodi DIII Keperawatan Poltekkes Sorong

\begin{tabular}{|c|l|c|c|c|}
\hline No & Area Kompetensi & $\begin{array}{c}\text { Rerata Jumlah } \\
\text { Jawaban Benar }\end{array}$ & Jumlah soal & $\begin{array}{c}\text { Persentase } \\
\text { Jawaban Benar }\end{array}$ \\
\hline 1 & KMB & 20,69 & 56 & 36,9 \\
\hline 2 & Maternitas & 7,88 & 22 & 35,8 \\
\hline 3 & Anak & 6,69 & 22 & 30,4 \\
\hline 4 & Jiwa & 6,81 & 22 & 30,9 \\
\hline 5 & Keluarga & 8,10 & 22 & 36,8 \\
\hline 6 & Gerontik & 4,40 & 12 & 36,6 \\
\hline 7 & Manajemen & 4,19 & 12 & 34,9 \\
\hline 8 & Gadar & 3,56 & 12 & 29,7 \\
\hline
\end{tabular}

Sumber : AIPViKI (2018)

Berdasarkan tabel 3.1 diatas dapat

dilihat bahwa area kompetensi yang memiliki persentase nilai tertinggi adalah KMB sedangkan yang terendah adalah 
Gadar. Berdasarkan hal tersebut maka project ini difokuskan untuk

\section{Deskripsi subyek penelitian}

Subyek penelitian adalah dosen dan mahasiswa program studi DIII Keperawatan Jurusan Keperawatan Politeknik Kesehatan Kemenkes Sorong. Dosen yang dijadikan responden adalah dosen yang mengajar mata kuliah Keperawatan Medikal Bedah I, Keperawatan Medikal Bedah II dan Keperawatan Gawat Darurat dan Manajemen Bencana berjumlah 3 orang. Selain dosen, mahasiswa juga dijadikan sebagai responden guna memvalidasi kembali hasil wawancara dengan dosen. Mahasiswa yang dijadikan sebagai responden adalah mahasiswa yang sudah mengikuti try out ujian kompetensi DIII Keperawatan periode Februari 2018 membandingkan proses pembelajaran kedua area kompetensi tersebut

berjumlah 4 orang. Pemilihan mahasiswa ini berdasarkan tingkat kehadiran pada saat perkuliahan dimana kehadirannya 100\% pada mata kuliah KMB I, KMB II, maupun Keperawatan Gawat Darurat dan Manajemen Bencana. Hal ini dilakukan agar informasi yang didapatkan dari mahasiswa benar-benar akurat terkait materi ajar, bahan ajar, metode pembelajaran, dan penilaian hasil belajar dari mata kuliah yang menjadi fokus project.

Project ini dilakukan pada tanggal 3 - 23 Oktober 2018 di Jurusan Keperawatan Politeknik Kesehatan Kemenkes Sorong. Karakteristik responden berdasarkan umur, jenis kelamin dan status responden sebagai berikut:

Tabel 3.2. Daftar Responden

\begin{tabular}{|c|c|c|c|c|}
\hline Kode & Responden & Umur & Jenis Kelamin & Status \\
\hline RD1 & YK & 55 Tahun & Laki-Laki & $\begin{array}{c}\text { Dosen KMB dan } \\
\text { Gadar }\end{array}$ \\
\hline $\mathrm{RD} 2$ & $\mathrm{ACM}$ & 27 Tahun & Laki-Laki & $\begin{array}{c}\text { Dosen KMB dan } \\
\text { Gadar }\end{array}$ \\
\hline RD3 & BS & 64 Tahun & Laki-Laki & Dosen KMB \\
\hline RM1 & FL & 22 Tahun & Perempuan & Mahasiswa \\
\hline RM2 & NAA & 21 Tahun & Perempuan & Mahasiswa \\
\hline RM3 & $\mathrm{EB}$ & 22 Tahun & Perempuan & Mahasiswa \\
\hline RM4 & FRR & 22 Tahun & Laki-Laki & Mahasiswa \\
\hline
\end{tabular}

\section{Deskripsi pelaksanaan evaluasi}

Beberapa hal yang harus diperhatikan dalam proses pembelajaran adalah materi ajar, bahan ajar, metode pembelajaran, penilaian hasil belajar, dan staf pengajar. Evaluasi dilakukan melalui wawancara mendalam terhadap dosen dan mahasiwa untuk memperoleh refleksi terhadap proses belajar mengajar.

1) Materi Ajar

Berdasarkan hasil wawancara terhadap dosen dan mahasiswa dan mencocokan dengan dokumen monitoring dosen ditemukan bahwa untuk mata kuliah KMB I dari 22 bahan kajian (materi ajar) semua materi (100\%) disampaikan. Mata kuliah KMB II dari 48 bahan kajian (materi ajar) terdapat 43 materi (91\%) yang disampaikan.. Mata kuliah Keperawatan Gawat Darurat dan Manajemen Bencana dari 16 bahan kajian (materi ajar) hanya 11 materi (68\%) yang disampaikan

\begin{tabular}{lrr}
\multicolumn{1}{c}{ Hal } & tersebut & kemudian \\
dikonfirmasi & kembali & kepada \\
responden (RM7) yang menyatakan :
\end{tabular}


“....salah satu dari 2 dosen Gadar sangat jarang masuk sehingga jumlah tatap muka kurang, seingat saya hanya 2-3 kali pertemuan dari yang seharusnya 7 kali..."

Selanjutnya peneliti menanyakan terkait kejelasan materi yang disampaikan oleh dosen, salah satu responden (RM6) menyatakan bahwa untuk mata kuliah KMB dosen menyampaikan materi dengan jelas khusunya dosen SR dan ACM, sedangkan Gadar terkadang mahasiswa tidak terlalu memahami materi yang disampaikan oleh dosen. Responden lainnya (RM5) menyatakan bahwa materi KMB menarik dan mudah dimengerti sedangkan untuk Gadar jumlah pertemuan tatap muka di kelas masih kurang namun mahasiswa sudah diarahkan untuk praktek klinik.

Sehingga dapat ditarik kesimpulan bahwa salah satu yang mempengaruhi tingginya persentase kelulusan mata kuliah KMB adalah kejelasan materi yang disampaikan dan seluruh materi disampaikan secara tuntas.

2) Bahan Ajar

Berdasarkan wawancara dengan responden, ditemukan bahwa mata kuliah KMB hampir seluruh dosennya memberikan bahan ajar yang bervariatif seperti buku, handout, modul, dan video, sedangkan untuk mata kuliah Gadar hanya satu dosen saja yang sering memberikan bahan ajar berupa video dan dosen lainnya hanya memberikan handout. Seperti yang diungkapkan oleh salah satu responden (RM4) :

“...Pak ACM yang paling sering minta kita untuk cari buku referensi di perpustakaan, Ibu SR juga sering kasih contoh kasus di kehidupan nyata. Pak ACM sering tampilkan video-video..."

Sehingga dapat ditarik kesimpulan bahwa bahan ajar yang bervariatif dan tidak hanya terpaku pada satu sumber berkontribusi terhadap hasil belajar mahasiswa termasuk hasil try out ujian kompetensi.

3) Metode Pembelajaran

Berdasarkan hasil wawancara terhadap responden ditemukan bahwa dosen mata kuliah KMB menggunakan berbagai metode dalam pembelajaran antara lain ceramah, diskusi, studi kasus, simulasi, praktek lab dan praktek klinik. Sedangkan untuk mata kuliah Gadar metode yang digunakan hanya ceramah. Saat peneliti menanyakan tentang kepuasan mahasiswa terhadap metode pembelajaran yang digunakan salah seorang responden (RM5) mengungkapkan :

“...Pak ACM dan bu SR di KMB menyampaikan materi dengan metode yang mudah kita mengerti. Dan KMB banyak dilakukan diskusi sedangkan Gadar monoton hanya ceramah, sebaiknya metode praktek lebih diperbanyak..."

Responden lain (RM6) mengungkapkan :

“...metode pembelajaran yang dilakukan Pak ACM bagus, mahasiswa cepat mengerti, sering memberikan contoh-contoh pada kehidupan nyata, begitu juga Ibu SR. Selain itu, pengalaman selama praktek sangat membantu menjawab soal pada saat try out. Contohnya praktek klinik KMB sudah mulai dilakukan dari semester III sampai semester VI sehingga pengetahuan yang didapat lebih banyak bila dibandingkan praktek klinik Gadar yang baru dilakukan pada semester V. Dan juga kasus gadar di RS kurang, kebanyakan kasus KMB..."

Salah seorang responden dosen (RD2) mengungkapkan bahwa metode pembelajaran KMB tidak terpaku pada satu metode saja, kadang ceramah, metode jigsaw, studi kasus, e-learning untuk ujian, praktek laboratorium dan praktek klinik selama 1 minggu. Sedangkan Gadar praktek klinik ada namun praktek laboratorium tidak ada. Saat ditanya kembali mengapa hal tersebut bisa terjadi, responden menjawab bahwa kurikulum inti dari 
pusat sudah seperti itu dan dari institusi tidak ada penambahan kurikulum. Yang ada di kurikulum institusi adalah asuhan keperawatan bencana, namun tidak menyentuh tentang penanganan gawat darurat itu sendiri.

Berdasarkan hal tersebut maka dapat ditarik kesimpulan bahwa penerapan metode pembelajaran yang inovatif di mata kuliah KMB memberikan pengalaman belajar yang lebih baik pada mahasiswa dan berpengaruh terhadap nilai try out ujian kompetensi.

4) Penilaian Hasil Belajar

Berdasarkan hasil wawancara dan telaah dokumen soal ujian ditemukan bahwa 3 dari 4 dosen KMB memberikan soal berbentuk vignette (kasus) pada saat UTS maupun UAS, sedangkan untuk mata kuliah Gadar soal ujian berbentuk pilihan ganda biasa. Hal ini berpengaruh terhadap kemampuan mahasiswa menjawab soal pada try out ujian kompetensi karena faktor terbiasa berhadapan dengan soal sejenis, seperti yang diungkapkan oleh salah satu responden (RM4) saat peneliti menanyakan mengenai kepuasan terhadap model penilaian hasil belajar yang dilakukan oleh dosen

“...kalau menurut saya masih kurang, seperti soal yang diberikan, dari semua

\section{PEMBAHASAN}

1. Materi Ajar

Sesuai dengan standar kompetensi, materi pembelajaran dapat dibedakan sesuai dengan prinsip pembelajaran aspek kognitif, afektif, dan psikomotorik. Materi pembelajaran aspek kognitif secara terperinci dapat dibagi menjadi empat yaitu: fakta, konsep, prinsip dan prosedur (Reigeluth, 1987). (1) Materi jenis fakta adalah materi berupa nama-nama objek, nama tempat, nama orang, lambang, peristiwa sejarah, nama bagian atau komponen suatu benda, dan lain sebagainya; (2) materi konsep berupa pengertian, definisi, hakekat, inti isi; (3) materi jenis prinsip berupa dalil, rumus, postulat adagium, paradigma, dosen hanya beberapa saja yang memberi soal seperti soal ukom..."

Hal serupa juga diungkapkan oleh responden dosen (RD2) bahwa dengan membiasakan mahasiswa terpapar dengan bentuk soal vignette dan metode pembelajaran yang tidak terfokus di dalam kelas membuat pengalaman mahasiswa lebih banyak dan lebih siap menghadapi ujian kompetensi.

5) Staf Pengajar

Berdasarkan hasil wawancara dan telaah dokumen diketahui bahwa bahwa 3 dari 4 dosen KMB memiliki kualifikasi S2 Keperawatan dengan spesialisasi KMB, sedangkan untuk mata kuliah Gadar semua dosen memiliki kualifikasi S2 Keperawatan namun bukan spesialisasi Gadar. Hal ini berpengaruh terhadap tercapainya kompetensi mata kuliah, seperti yang diungkapkan oleh salah satu responden (RD2) :

“....saya mengajar di Gadar tapi sebenarnya saya lebih expert di KMB karena saya spesialisasi KMB, sehingga saya merasa kurang dalam menyampaikan materi Gadar meskipun sudah mengikuti pelatihan. Jadi saya lihat dosen terkesan dipaksakan mengajar Gadar..."

teorema; dan (4) materi jenis prosedur berupa langkah-langkah mengerjakan sesuatu secara urut, misalnya langkahlangkah pemeriksaan fisik. Identifikasi kebutuhan atau standar kompetensi merupakan hal pokok pemilihan materi pembelajaran. Hal ini berarti bahwa materi pembelajaran yang dipilih untuk diajarkan oleh pendidik di satu pihak dan harus dipelajari peserta didik hendaknya berisikan materi atau bahan ajar yang benarbenar menunjang tercapainya standar kompetensi dan kompetensi dasar. Dengan kata lain, pemilihan materi pembelajaran haruslah mengacu atau merujuk pada standar kompetensi. Untuk memilih itupun perlu pengetahuan, karena pengetahuan merupakan proses belajar manusia mengenai kebenaran atau jalan 
yang benar untuk dilakukan. Selain itu juga diperlukan keterampilan yang merupakan kemampuan untuk mengorganisasikan antara kompetensi dengan materi pembelajaran agar secara mudah dan cermat menentukannya.

Berdasarkan hasil observasi terhadap dokumen monitoring dosen mata kuliah KMB 1, KMB II, maupun Keperawatan Gawat Darurat diperoleh hasil bahwa terdapat perbedaan persentase materi yang disampaikan dimana KMB persentasenya lebih tinggi dibanding Gadar, kemudian hal ini dicrosscheck kembali dengan responden. Data yang diperoleh dari responden dimana ada responden (R5) yang mengungkap bahwa materi yang diberikan pada mata kuliah keperawatan gawat darurat memang tidak tuntas. Responden dosen (R2) juga mengatakan demikian. Sehingga bisa ditarik kesimpulan bahwa penyampaian materi yang tidak tuntas berkontribusi dalam rendahnya nilai try out ujian kompetensi.

\section{Bahan ajar}

Bahan ajar merupakan seperangkat materi atau substansi pembelajaran (teaching material) yang disusun secara sistematis dan menampilkan sosok utuh dari kompetensi yang akan dikuasai oleh mahasiswa dalam kegiatan pembelajaran. Dengan bahan ajar memungkinkan mahasiswa dapat mempelajari suatu kompetensi secara runtut dan sistematis sehingga secara akumulatif mampu menguasai semua kompetensi secara utuh dan terpadu.

Bahan ajar adalah segala bentuk bahan yang digunakan untuk membantu dosen dalam melaksanakan kegiatan belajar mengajar di kelas. Bahan yang dimaksud bisa berupa bahan tertulis maupun bahan tidak tertulis.

Proses pembelajaran merupakan suatu rangkaian kegiatan aktifitas dalam upaya perwujudan kompetensi siswa, dibangun oleh berbagai unsur, yaitu unsur raw input, instrumental input (terdiri dari tujuan, materi berupa bahan ajar, media dan perangkat evaluasi) yang berfungsi sebagai perangkat yang akan memproses pembentukan kompetensi, serta perangkat lingkungan (environmental input), seperti lingkungan keluarga, sekolah maupun masyarakat, yang turut mempengaruhi keberhasilan pencapaian kompetensi.

Bahan pembelajaran menempati posisi penting dalam proses pembelajaran. Tanpa bahan ajar mustahil pembelajaran akan terwujud. Tepat tidaknya bahan ajar dengan tujuan dan kompetensi yang diharapkan akan menentukan tercapai tidaknya tidaknya tujuan kompetensi pembelajaran yang diharapkan.

Beradasarkan hasil wawancara terlihat bahwa untuk KMB bahan ajar yang digunakan sangat mendukung pencapaian kompetensi seperti yang diungkapkan oleh responden dosen (R2) :

“....Saya siapkan modul untuk mahasiswa, selain buku dari perpustakaan. Saya punya bank buku ebook yang saya gunakan untuk mengajar, tapi tidak dikasih ke mahasiswa karena berbahasa inggris. Di dalam materi saya pun saya selipkan hasil-hasil penelitiaan dari jurnal-jurnal terbaru. Untuk Gadar saya ambil dari materi pelatihan gadar sehingga up to date, tapi meskipun demikian saya merasa tidak terlalu dalam untuk pencapaian kompetensi Gadar karena saya tidak expert disitu, background saya KMB begitu juga dengan Pak Yoel..."

Sehingga dapat disimpulkan bahwa selain dari bahan ajar, background pendidikan dosen juga sangat menentukan tercapainya kompetensi mata kuliah. Oleh karena itu, dalam penentuan dosen tiap mata kuliah sangat perlu mempertimbangkan latar belakang keilmuan dosen.

3. Metode Pembelajaran

$$
\text { Metode pembelajaran }
$$
merupakan cara-cara yang digunakan dosen untuk menyajikan informasi atau pengalaman baru, menggali pengalaman peserta didik, menampilkan unjuk kerja peserta didik dan lain-lain. Pemilihan metode yang tepat tentu saja harus mempertimbangkan banyak hal, seperti kondisi dan kemampuan awal siswa, sarana-prasara, media, kemampuan guru, dan lain-lain. Belum tentu metode ceramah lebih buruk daripada metode diskusi atau demonstrasi. Terdapat 
beberapa metode mengajar, sehingga dengan mendeskripsikan setiap unsur yang terlibat dala pembelajaran tersebut dapat ditengarai ciri pembelajaran yang berpusat pada siswa (student centered learning).

Terdapat beragam metode pembelajaran untuk student centered learning, di antaranya adalah: (1) small group discussion; (2) role-play \& simulation; (3) case study; (4) discovery learning (DL); (5) selfdirected learning (SDL); (6) cooperative learning (CL); (7) collaborative learning ( $\mathrm{CbL})$; (8)contextual instruction (CI); (9) project based learning ( $\mathrm{PjBL})$; dan (10) problem based learning and inquiry (PBL).

Dalam prakteknya, metode mengajar hampir tidak mungkin apabila digunakan secara terpisah atau sendirisendiri. Pada umumnya dosen melakukan kombinasi dari berbagai metode mengajar di atas.

Keberhasilan dalam proses pembelajaran lebih terletak pada kemampuan dosen dalam meramu atau mengkombinasikan berbagai metode mengajar yang ada. Dalam kenyataannya, masih banyak dijumpai dosen yang menerapkan metode mengajar teacher centered learning atau kurang adanya kombinasi atau inovasi, sehingga pembelajaran kurang efektif.

4. Penilaian Hasil Belajar

Penilaian hasil belajar merupakan proses mulai menentukan objek yang diukur, mengukurnya, mencapai hasil pengukuran, mentransformasikan ke dalam nilai, dan mengambil keputusan lulus tidaknya peserta didik. Efektif tidaknya dosen mengajar atau baik buruknya interaksi antara dosen dan peserta didik dalam proses pembelajaran. Pada umumnya dosen menggunakan ujian untuk mengukur dan menilai hasil belajar peserta didik. Ujian dapat berfungsi sebagai alat mengevaluasi efektivitas peserta didik belajar, efektivitas proses pembelajaran oleh dosen, disamping itu berfungsi sebagai instrumen pengukuran dan penilaian kemampuan peserta didik dalam mencapai tujuan pembelajaran.

Penilaian mempunyai peran utama dalam proses pembelajaran, jika pendidik melakukan penilaian peserta didik mereka harus mempunyai pemahaman tentang penilaian proses pembelajaran dan menggunakan instrument yang tepat untuk menilai setiap hasil pembelajaran. Harden \& Crosby (2002) mengemukakan bahwa proses penilaian peserta didik merupakan peran penting atau tanggung jawab seorang pendidik. RPS sangat membantu dosen dalam merencanakan penilaian peserta didik yang efektif dan efisien karena dasar penyusunannya mengacu pada learning objective yang ingin dicapai.

Perencanaan pembelajaran yang memadai merupakan hal penting dalam pelaksanaan ujian yang valid. Selain itu dosen dapat menyesuaikan antara learning objective dengan instrumen penilaian yang akan digunakan. Hal ini dapat berpatokan pada piramida Miller. Instrumen yang digunakan dalam penilaian peserta didik disesuaikan dengan kompetensi dan tujuan pembelajaran yang ingin dicapai. Bila tujuan penilaian hanya ingin melihat tingkat pengetahuan (knows, and knows how), maka instrument yang digunakan adalah bentuk tes tertulis (written assessment), contohnya: modified essay question, multiple choice question) atau tes lisan dengan wawancara (interview). Namun, bila tujuan ingin sampai pada mengetahui cara dan dapat melakukan (shows dan does), maka instrument penilaian yang digunakan adalah dalam bentuk ujian praktek skills lab dan praktek klinik rumah sakit. Contohnya: long case; practical examination; Spot Examination Objective Structured Clinical Examination (OSCE); Objective Structured Practical Examination (OSPE); Objective Structured Long Examination Record (OSLER); Group Objective Structured Clinical Examination (GOSCE).

Instrumen penilaian dapat digambarkan sesuai dengan kriteria yang ditentukan validitas terkait dengan kesahihan sedang realibilitas dengan konsistensi. Untuk menyusun materi ujian yang valid, dosen dapat mengacu pada RPS, sedangkan untuk realibilitasnya dapat dirancang dengan mempertimbangkan efisiensi dari segi 
waktu, penilaian, dan format penilaian serta ragam tingkat kesulitan. Tujuan penilaian adalah untuk membantu belajar peserta didik, mengidentifikasi kekuatan dan kelemahan peserta didik, menilai efektivitas strategi pembelajaran, menilai dan meningkatkan efektivitas kurikulum, menilai dan meningkatkan efektifitas pembelajaran. Tujuan evaluasi pembelajaran adalah untuk mengetahui keefektifan dan efisiensi sistem pembelajaran baik tujuan, materi, metode, media, sumber belajar, lingkungan maupun sistem penilaian sendiri.

5. Staf pengajar

Peningkatkan
pengembangan staf pengajar akan
berdampak positif terhadap kualitas
pengajaran dan pembelajaran, sehingga
berdampak terhadap kualitas lulusan
mahasiswa.( Harden RM, Crosby J.
,2000; ). Keterampilan dasar mengajar
harus dimiliki setiap oleh staf pengajar.
Selain penguasaan materi pembelajaran,
staf pengajar sebaiknya juga menguasai
cara mengajar. Mengajar bukan hanya
sekedar penyampaian materi tetapi

\section{REFERENSI}

1. Kemenristekdikti. 2016. Implementasi Uji Kompetensi Nasional bidang Kesehatan sebagai Langkah Konkrit Penjaminan Mutu Pendidikan Tinggi Kesehatan.

(https://ristekdikti.go.id/implementasiuji-kompetensi-nasional-bidangkesehatan-sebagai-langkah-konkritpenjaminan-mutu-pendidikan-tinggikesehatan/) diakses tanggal 10 Juli 2018.

2. Sukmadinata N. 2007. Metode Penelitian Pendidikan. Bandung: PT Remaja Rosdakarya.

3. Sudjana, Nana. 2000. Dasar-Dasar Proses Belajar Mengajar. Bandung: Sinar Baru Algesindo.

4. Nasution, S. 1989. Kurikulum dan Pengajaran. Jakarta : Bina Aksara.

5. AIPViKi. 2018. Hasil Try Out Uji Kompetensi Nasional Program DIII Keperawatan Priode 10 Februari 2018. Jakarta.

6. Sugiono. 2012. Memahami Penelitian Kualitatif. Jakarta : EGC mencakup pembinaan sikap, emosional, karakter , kebiasaan, dan nilai-nilai moral.( Khairani M.,2013).

\section{KESIMPULAN}

Tingginya persentase kelulusan KMB pada hasil try out ujian kompetensi dipengaruhi oleh bagaimana dosen melakukan proses pembelajaran antara lain materi ajar disampaikan secara tuntas dan jelas, bahan ajar yang menggunakaan referensi dari berbagai sumber, metode pembelajaran yang variatif dan inovatif, penilaian hasil belajar menggunakan soal serupa dengan ujian kompetensi, dan staf pengajar yang sesuai dengan kualifikasi. Hal ini berbanding terbalik dengan mata kuliah Keperawatan Gawat Darurat yang memiliki persentase kelulusan terendah.

Untuk itu diharapkan adanya evaluasi secara rutin melalui unit penjaminan mutu Poltekkes Kemenkes Sorong dengan melakukan audit internal terhadap proses pembelajaran agar pelaksanaan pembelajaran berjalan secara efektif dan efisien yang pada akhirnya dapat meningkatkan kelulusan ujian kompetensi.

7. Semiawan, Conny. 2010. Metode Penelitian Kualitatif, Jenis Karakteristik, dan Keunggulannya. Jakarta : Gramedia. 